\title{
Xanthomonas arboricola Diseases of Stone Fruit, Almond, and Walnut Trees: Progress Toward Understanding and Management
}

\author{
Jay Ram Lamichhane \\ French National Institute for Agricultural Research (INRA), UAR 1240 Eco-Innov Research Unit, \\ 78850 Thiverval-Grignon, France
}

Stone fruit (Prunus spp.: apricot, cherry, peach, nectarine, plum, and sloe), almond (Prunus spp.) $(37,104)$, and walnut (Juglans spp.) (53) crops are among the most economically important tree crops worldwide and are cultivated to a different extent on all continents (25) (Table 1). The number of countries growing these crops has increased in the last decade with a subsequent increase in acreage globally (25). Consumer health awareness in recent years has created a demand for food sources with higher therapeutic properties. More specifically, stone fruits and nuts are rich in antioxidants and omega-3 fatty acids, essential in preventing or reducing the risk of cancers and heart disease $(12,95)$.

Throughout the range of cultivation, Prunus spp. and Juglans spp. are often subjected to pathogen attack. Among them, Xanthomonas arboricola has become markedly important over the last decade. The putative pathovars of $X$. arboricola, pv. pruni and pv. juglandis, cause bacterial canker and spot (90) and bacterial blight (91) on stone fruits and almond, and on walnut, respectively. Besides cultivated species, all the ornamental Prunus species and hybrids can be affected by this bacterium (94). Of these, Japanese plum, peach, and nectarines are the most affected (79).

In recent years, disease outbreaks caused by $X$. arboricola on Prunus and on Juglans have increased, as has international concern. In the last decade, disease outbreaks have been reported from Iran (36), Spain (71), Switzerland (74), Taiwan (87), and the United States (S. K. Mohan and V. Bijman, unpublished), and on ornamental Prunus spp. from Italy (54) and the Netherlands (97). Similarly, recent outbreaks on walnut were reported from France (32), Iran (30), Lithuania (15), and Turkey (68). The rate at which these outbreaks are occurring suggests the possibility of future epidemics. To address the consequences of such disease emergences, it is important to understand the epidemiology of these diseases, about which little is known to date.

Both bacterial canker and spot on Prunus spp. (90) and bacterial blight on Juglans spp. (91) were first described in the United States at the beginning of the twentieth century. Since then, the diseases have spread throughout the globe (16). X. arboricola is listed as a quarantine organism in the EU phytosanitary legislation (EU Directive 2000/29/CE) and in the European and Mediterranean Plant Protection Organization (EPPO A2 list) lists (21). In contrast, $X$. arboricola infecting Prunus spp. is not considered of quarantine concern by any other regional plant protection organizations.

Corresponding author: J. R. Lamichhane,

E-mail: jayram.lamichhane@gmail.com,

Jay-Ram.Lamichhane@grignon.inra.fr,

Phone: +33(0)130815415, Fax: +33 (0)130815207

http://dx.doi.org/10.1094/PDIS-08-14-0831-FE

(c) 2014 The American Phytopathological Society
Overall, the spread of phytopathogenic bacteria occurs through multiple short- and long-distance dissemination pathways. Cultural practices (grafting, pruning, etc.) and vectors such as mites or insects are the major source of local dissemination, while winddriven rain, aerosol, and the inter-regional, national, and continental trade of nursery materials are the major sources of long-distance movement of plant-pathogenic bacteria $(40,49)$. Some phytopathogenic bacteria, such as $X$. arboricola, are able to infect fruit and nuts $(23,59)$ and consequently might be introduced at long distances through imported fruit. Of these dissemination pathways, dissemination through international trade of infected nursery material is the most serious problem for the effective control of plantpathogenic bacteria (40). Because of their relatively long life cycle, stone fruits and nuts provide a constant niche for the survival and multiplication of bacterial pathogens. Bacterial pathogens might survive in woody plant tissues that provide protection against adverse climatic conditions or man-made control treatments. Latent infections markedly increase the risk of dissemination through vegetative propagation $(44,47)$. This method is the most practiced technique for propagation of woody plants and can easily lead to the spread of latent infections. For this reason, propagation of disease-free plants in nurseries is an important step in producing pathogen-free planting material.

A previous study on the effect of $X$. arboricola on Prunus spp. reported three major economic factors: (i) reduced quality and marketability of fruit, (ii) reduced orchard productivity, and (iii) increased costs of nursery production. This study estimated that crop losses in Australia during years favorable to the disease were 3.1 million Australian dollars annually on Prunus spp. (94). Similarly, economic losses in Italy during epidemic years were estimated at over 10, $000 €$ per ha (94). During years of severe infection, 25 to $75 \%$ of peach fruit has been reported as unmarketable (22). Bacterial blight of walnut can cause reductions in yield up to $70 \%$ as the pathogen attacks all herbaceous and woody parts of the plant $(50,59,60)$.

The objectives of this review are (i) to provide an overview of $X$. arboricola diseases of stone fruit, almond, and walnut trees, and (ii) to discuss current and future management strategies. The focus is not on the detection and identification of $X$. arboricola from stone fruit and nuts nor on $X$. arboricola disease of hazelnut, which have been described elsewhere $(38,47,69,70,73)$.

\section{Taxonomic Relationships}

The Xanthomonas arboricola complex includes phytopathogenic bacteria responsible for emerging diseases worldwide $(13,32,47)$. This species, currently divided into seven pathovars $(39,102)$, causes diseases in a range of perennial plants such as hazelnut, poinsettia, poplar, Prunus spp., and Juglans spp. $(39,72,79,102)$. X. arboricola infecting Prunus spp. and hazelnut 
(the putative pv. pruni and pv. corylina, respectively) are listed as quarantine organisms in the EU phytosanitary legislation (EU Directive 2000/29/CE) and in the European and Mediterranean Plant Protection Organization lists (EPPO A2 list) $(21,22)$. The phylogenetic relationships, based on the $r p o D$ housekeeping gene, among a worldwide collection of $X$. arboricola revealed that strains isolated from poplar are divergent from the main $X$. arboricola cluster formed by all other strains (33). At the same time, strains isolated from Prunus spp. (pv. pruni) constitute a homogeneous group from all other pathovars, which in turn are quite heterogeneous $(33,77,102,111)$.

The initial taxonomy of the genus Xanthomonas was based on the original host of isolation, which led to a large number of species (14). A further work, based on the phenotypic characteristics, clustered the Xanthomonas isolates into eight phenotypic groups (100). Immediately after this work, Vauterin et al. (102) reclassified the Xanthomonas species on the basis of DNA-DNA hybridization. This reclassification grouped the Xanthomonas species into different categories, and pathogens of trees have been renamed $X$. arboricola. All currently named $X$. arboricola pathovars came from a group of bacteria previously named $X$. campestris. The exception is the strawberry pathogen, pv. fragariae, which was not described at the time. The species name "arboricola," from Latin "tree dwellers," was first attributed by Vauterin et al. (102) and justified by including bacteria that live and cause diseases of tree species.

Although attempts to clarify the naming of pathovars have been made since 1978 (20,110), confusion still exists. According to the standards, for designating a novel pathovar, it is necessary to demonstrate by pathogenicity tests that the pathogen has a distinct host range or causes a distinct disease when compared with previously described pathogens. However, to date, no host range study of $X$. arboricola pathovars, renamed from $X$. campestris, was performed. Debate continues with regard to what constitutes different pathovars among plant-pathogenic bacteria $(49,101)$. For example, in their comparative study with strains of $X$. arboricola pv. populi,

Table 1. Harvested areas (ha) of fruit and nut crops throughout the world (FAO 2012)

\begin{tabular}{|c|c|c|c|c|c|c|}
\hline \multirow[b]{2}{*}{ Continents } & \multicolumn{4}{|c|}{ Stone fruits } & \multicolumn{2}{|c|}{ Nuts } \\
\hline & Apricot & Cherry & Peach and Nectarine & Plum and Sloe & Almond & Walnut \\
\hline Asia & 294,929 & 148,588 & 982,736 & $1,875,850$ & 214,107 & 641,314 \\
\hline Africa & 79,092 & 5,259 & 82,843 & 46,730 & 441,148 & 8,381 \\
\hline Northern America & 5,014 & 36,613 & 59,036 & 33,906 & 315,590 & 98,980 \\
\hline South America & 3,957 & 17,899 & 84,093 & 45,047 & 9,021 & 25,547 \\
\hline Oceania & 6,734 & 2,819 & 19,861 & 3,362 & 28,500 & 8,074 \\
\hline World & 491,896 & 401,644 & $1,463,656$ & $2,516,362$ & $1,651,779$ & 925,244 \\
\hline
\end{tabular}

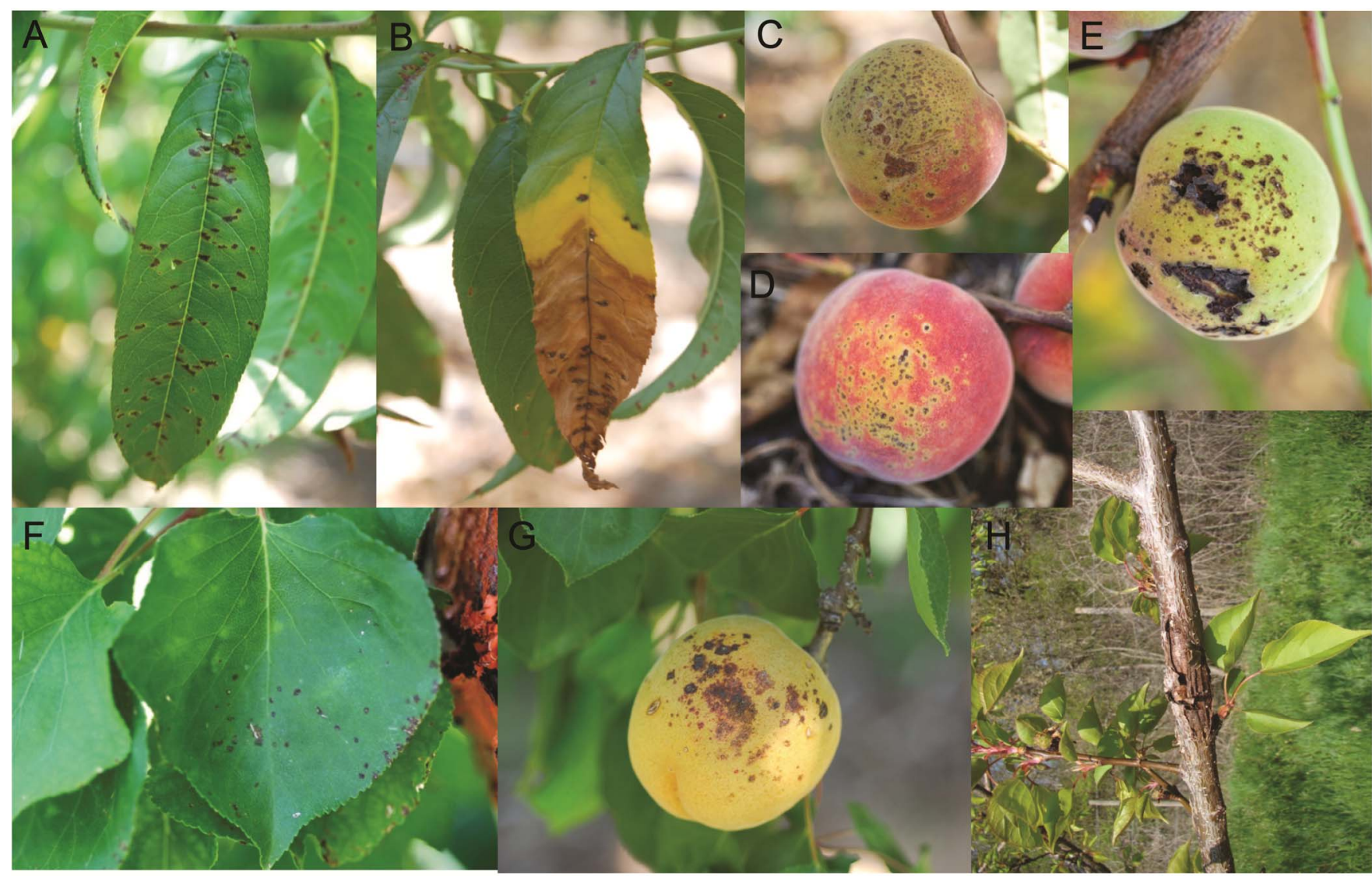

Fig. 1. Symptoms of bacterial spot and canker caused by Xanthomonas arboricola pathovars on stone fruit. Leaf spots (A) followed by yellowing and browning (B) and characteristic lesions on peach fruit (C, D, and E). Necrotic lesions on apricot leaves (F) and fruit (G) and a characteristic twig canker (H). Photos courtesy of M. Cambra except part $\mathrm{H}$, which belongs to the author. 
Hajri et al. (33) observed that even more pathovars belonging to the $X$. arboricola complex may harbor a variety of assorted strains. These results suggest that populations of $X$. arboricola are common plant residents and their presence in association to plants does not necessarily imply pathogenic behavior. Indeed, Sawada et al. (83) reported the presence of phylogenetically diverse pectolytic $X$. arboricola strains associated with bacterial spot of grapevine. However, the authors did not propose a new pathovar due to the diversity and weak pathogenicity of the strains. Recently, $X$. arboricola has also been reported to cause disease on jujube (Zizyphus zuzuba) (61) and on mango (Mangifera indica L.) (76), other woody plants. Also here, the authors refrained from proposing a new pathovar. Indeed, during the pathogenicity tests, strains isolated from one species also caused disease on other species (62), indicating that they can infect a broad host-range. Similar reports on the lack of host specificity of another plant-pathogenic bacterium, Pseudomonas syringae, have been recently reviewed on a large number of woody (49) and annual (J. R. Lamichhane, A. Messean, and C. E. Morris, unpublished) plants. Taken together, it can be speculated that the current $X$. arboricola pathovars might have a wider host range than expected. Therefore, before assigning the term pathovar to a new causal agent on a new host species, the host range of existing pathovars should be investigated.

\section{Disease Symptoms}

Bacterial canker and spot of Prunus spp. Overall, both herbaceous (leaves, buds, young shoots, fruit and nut shells) and woody (twigs, branches, and main trunk) plant parts can be affected by the disease (23,58,81; Figs. 1 and 2). However, no symptoms occur on the flowers. Symptoms of $X$. arboricola on stone fruit trees are reported to differ throughout the range of cultivation. In Italy, bacterial spot differs from those commonly described (6). The authors reported that symptoms occur only on leaves and fruit of peaches and nectarines, while canker symptoms occur on the branches and trunks of plum.

On peach leaves, symptoms first appear on the lower surface as pale green to yellow, circular or irregular areas with a light tan center. Over the time, symptoms enlarge and also appear on the upper leaf surface, where angular, deep-purple, brown or black spots are visible (Fig. 1A). The tissue surrounding these spots may turn yellow. Spots are generally concentrated at the leaf tip where bacteria accumulate in rain or dew droplets. Severely infected leaves turn yellow (Fig. 1B) and drop from the plant. On peach fruit, small brown spots appear on the surface and become sunken over time (Fig. 1C and D). Often, the margins of the spots are water-soaked, and light green haloes may develop, giving the fruit a mottled appearance. Pitting and cracking may occur in the vicinity of the spots as the fruit enlarges (Fig. 1C to E). These cracks are usually small and difficult to see but became extensive if young fruits are heavily infected. A gummy exudate may ooze from the wounds, especially after rain, and may be confused with damage caused by insects. On peach twigs, cankers occur in the spring at the apex of overwintering twigs. Symptoms begin with small, water-soaked, slightly darkened, superficial blisters that may extend up to $10 \mathrm{~cm}$ along the twig. During severe infections, the whole twig may be girdled and cause tip dieback. When the lower part of the tip also becomes dark, this is known as "black-tip" injury. Early twig infections often lead to cankers late in the summer. These

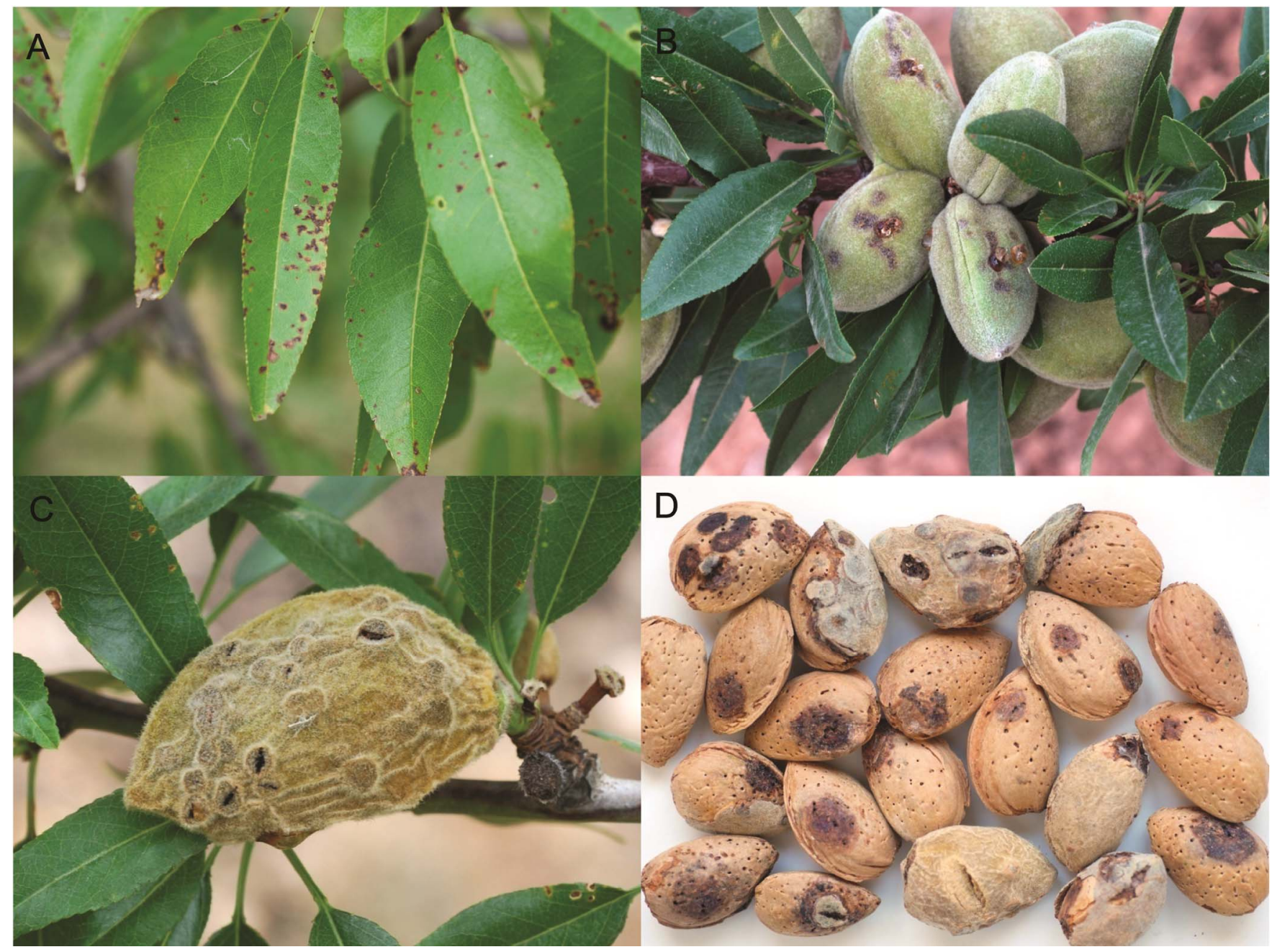

Fig. 2.Typical symptoms of Xanthomonas arboricola on almond. Necrotic spots surrounded by chlorotic haloes on leaves (A), sunken and corky lesions with oozing gum on fruit (B), lesions on a nut with dehydrated mesocarp (C), and dark brown spots on the nut endocarp (D). Photos courtesy of M. Cambra. 
cankers are water-soaked, and dark-purple spots form around the lenticels.

Unlike the cankers on peach, those on plum are perennial and develop continuously on young twigs. The inner bark of the twigs is often penetrated by the pathogen, leading to the formation of large cankers that deform and kill the twigs. On plum fruit, symptoms are similar to those observed on peach fruit. However, sunken black lesions may develop on some cultivars. Symptoms on apricot leaves (Fig. 1F) and fruits (Fig. 1G) are also similar to those on peach, while those on twigs (Fig. $1 \mathrm{H}$ ) resemble those observed on plum. Likewise, leaf symptoms on cherries are similar to those on peach, but fruit symptoms are uncommon. In some cases, however, early infections on cherries may cause distorted fruits.

On almond, leaf symptoms are similar to those observed on peach (Fig. 2A). In early spring, infected fruits show sunken corky lesions with oozing gum that streams or clumps (Fig. 2B). The sunken lesions become raised following dehydration of the mesocarp in summer (Fig. 2C). Sometimes circular dark spots appear on the endocarp and may affect the nut (Fig. 2D). Infected fruits either fall prematurely or remain attached to the trees and mummify over time. Mummified fruits harbor viable bacteria and serve as potential inoculum sources (81).

Bacterial blight of walnut. As with Prunus spp., bacterial blight on Juglans spp. affects all parts of the plant (Fig. 3). On walnut, however, even flowers (catkins) are subjected to the infection. In general, dark brown to black spots develop on new leaves, stems, and the apical portion of fruit shells (59,63; Fig. 3). Lateseason infections on maturing nuts can discolor the shell and nutmeats, making them off-grade or unsalable. In severe infection, many nuts may fall prematurely, while others reach full size. In these remaining nuts, the kernel often becomes blackened, dried, and wrinkled (26). X. arboricola is also a primary causal agent of a disease complex called brown apical necrosis. Other associated pathogens include fungi, especially species of Alternaria and Fusarium (8). In addition to the usual cankers on walnut, $X$. arboricola also causes a newly reported vertical oozing canker

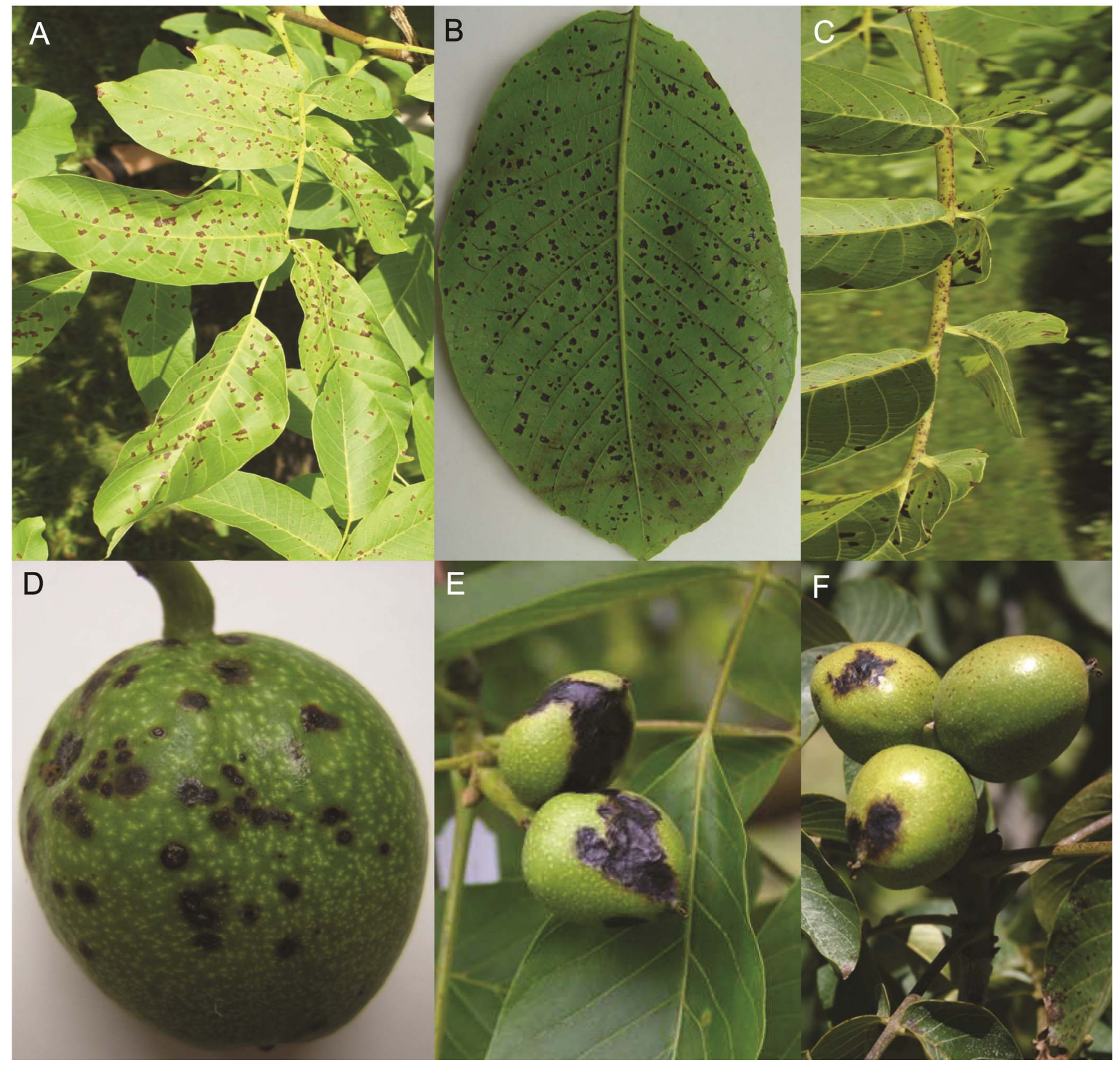

Fig. 3.Typical symptoms of bacterial blight on walnut. Necrotic lesions surrounded by chlorotic haloes on upper leaf surfaces (A); necrotic lesions on a lower leaf surface (B), stem (C) and nut (D); and apical necrosis on nuts (E and F). Photos courtesy of Daiva Burokiene (A, B, and D), Antonia Ninot (C), and Katherine Evans (E and F). 
$(32,59)$. Vertical cankers appear on the main trunk, which often lead to trunk deformities. During summer, infected trees form black oozing exudates that stain the bark (32).

\section{Epidemiology and Predisposing Factors}

Ground-cover and weeds, within and outside of orchards, are one of the most important reservoirs of plant-pathogenic bacteria, such as Pseudomonas syringae (19,52), Xanthomonas campestris (99), and Xylella fastidiosa (86). However, no studies have been published on the role of weeds and orchard ground-covers as reservoirs of $X$. arboricola. Future studies should address such issues with potential implications for the establishment of $X$. arboricola and its management.

Infected dormant buds, leaf scars, and cankers previously formed on woody plant parts are sources of primary inoculum on Prunus spp. and Juglans spp. (6,60,79,113; Fig. 4). These plant parts are commonly typical overwintering sites of the pathogen (60,79,113). On Prunus spp., Zaccardelli et al. (113) reisolated a field inoculated, rifampicin-resistant mutant from overwintered leaves. However, they were not able to reisolate the wild-type strain from naturally infected fallen leaves showing leaf spots. This raises questions on the survival capacity of $X$. arboricola on fallen leaves. Further studies are needed to determine if fallen leaves might be another source of primary inoculum in the following season.

Once $X$. arboricola from overwintering sites infects newly formed leaves in the spring, it multiplies epiphytically on Prunus and Juglans trees. The bacteria can switch from a saprophytic to a parasitic lifestyle and penetrate through natural openings like stomata. They can also enter plants through wounds caused by both natural (leaf drop, hail, frost) and man-made acts (pruning, harvesting) $(9,47,88)$. For this reason, infections are more frequent and severe during vegetative growths in the spring, especially when accompanied by frequent rainfalls.

Epiphytic $X$. arboricola pv. pruni populations may be produced by asymptomatic presence of bacteria (57) or by exudate forming leaf lesions that persist on leaves (88) and serve as inoculum on peach fruit. The same is true for plums (7) and walnuts (60). In addition, $X$. arboricola is capable of penetration through leaf scars, following leaf shedding in autumn, which then can become an overwintering site $(84,113)$.

Both leaf wetness and water congestion can markedly influence the establishment of infection (115). Experimental studies showed that a continuous film of water extending from the leaf surface

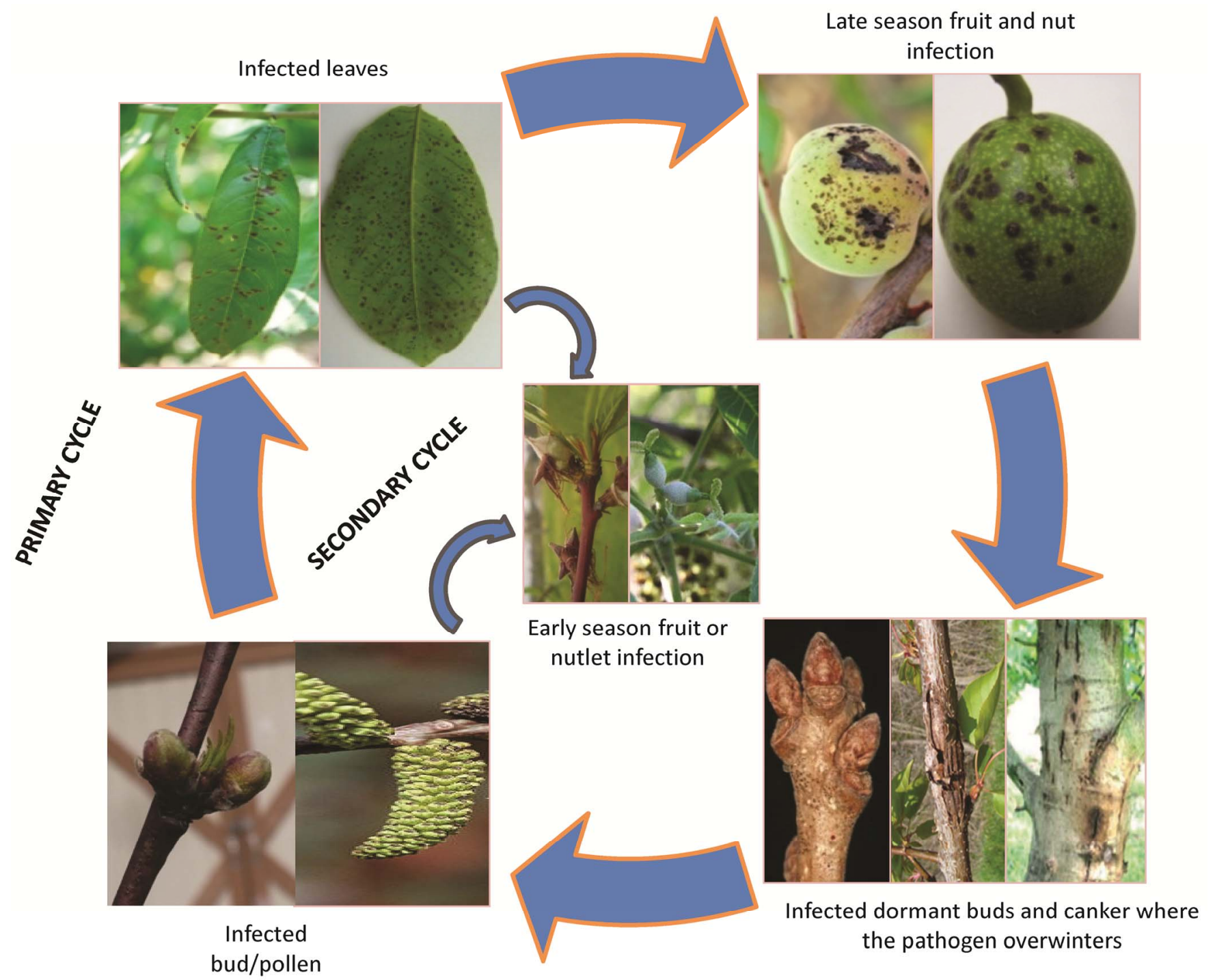

Fig. 4. Disease cycle of Xanthomonas arboricola on Prunus spp. and walnut. Infected dormant buds, leaf scars, and cankers are sites where the pathogen overwinters. These plant parts are sources of primary inoculum of the pathogen. In mid to late spring, $X$. arboricola begins to multiply and spread to newly formed leaves where it has an epiphytic phase. The pathogen switches from a saprophytic to pathogenic lifestyle once climatic conditions are conductive. Leaf infections generally occur from mid to late spring, and leaf lesions provide the inoculum for late season fruit and nut infections. The pathogen can infect woody tissues when these are wounded, and the infection could occur until late autumn. Catkins and newly formed buds could also be latently infected already in winter. Infected leaves, buds, and catkins are sources of secondary inoculum of the pathogen that infects newly formed fruits and nuts. 
through stomata into the substomatal chamber is necessary for penetration of $X$. arboricola into leaves and development of symptoms $(55,56)$. Another experimental greenhouse study showed the development of only slight necrosis when water-congested leaves were allowed to dry immediately after inoculation or to remain wet up to 18 hours (115). However, necrosis levels increased once leaf surface remained wet 24 to 48 hours. This explains that the duration of leaf wetness influences the severity of disease.

It is also important to note that the number of lesions induced by $X$. arboricola on peach was directly proportional to the inoculum concentration (18). A previous study reported that the time of symptom appearance does not influence disease progress, but that progress of the infection influences symptom development (6). The authors proposed two factors to explain this finding: (i) the weather was warmer and drier and so less favorable for disease development, and (ii) shoot growth had ceased and emergent leaves were mature. Zehr and Shepard (115) also found that necrosis after experimental inoculation is most severe on the youngest leaves.

Leaf lesions provide secondary inoculum that readily infects both early and late-season fruit and nuts (Fig. 4). Concerning lateseason fruit infection, in peach, fruit were affected later in the season than leaves with lower incidence and severity (6). This could be related to the lower density of stomata on the fruit surface compared to leaves. In addition, fruit are not subject to water congestion because their stomata chambers are less influenced by the hydrostatic pressure of the xylem. A delay in disease appearance on fruit compared to that on leaves was previously reported $(82,88)$, as well as a lack of correlation between leaf and fruit infection (105).

Diseases caused by $X$. arboricola show a typical start/stop pattern, the severity of which depends mostly on spring weather conditions. According to Stefani (94), the unpredictable pattern of bacterial epidemics experienced in different regions of the world may be related to: (i) differential pathogenicity features of bacterial strains, (ii) variations in susceptibility of plant species and cultivars, and (iii) cropping conditions, such as irrigation, fertilization, and pruning time and frequency.

The occurrence of primary and secondary infections on Prunus spp. and Juglans spp. depends mainly on environmental conditions. Frequent periods of moisture from late bloom to a few weeks after petal fall are highly conducive to primary infections on fruit and leaves of peaches and nectarines (6). Warm seasons with temperatures of 19 to $28^{\circ} \mathrm{C}$, frequent rains, winds, and heavy dews during the growing season can favor the development of secondary infections $(24,115)$. By contrast, few infections occur when the climate is warm and dry (79) as when it is cool, given that X. arboricola is a mesophylic bacteria and requires temperatures over $20^{\circ} \mathrm{C}$ for its reproduction (115).

Disease incidence is highly correlated with cultural practices and stress caused by unfavorable soil and climatic conditions $(28,46,55,84,115)$. Bacterial canker and spot of Prunus spp. are more common and most severe in areas where stone fruits are grown on light, sandy soils and the environment is humid and warm during the growing season. Stress factors such as spring frost, drought, and winter pruning predispose plants to bacterial blight (47). Moreover, nutrient deficiency and excessive mineral fertilization predispose plants to X. arboricola (106). The occurrence of spring frost can create micro-lesions on plant tissues through which $X$. arboricola may enter and establish infection (46).

\section{Pathogen Diversity}

An in-depth knowledge of pathogen diversity is critical in developing reliable detection methods. Very low levels of diversity were reported among $X$. arboricola strains isolated from Prunus spp., and high levels from walnut. However, it should be highlighted that these strains have been isolated exclusively from diseased plant tissues without considering $X$. arboricola populations from the healthy plants. Because this pathogen is an epiphyte, a surprising population diversity might be present on annual weeds and orchard ground-covers and on perennial plants. Further investigations are needed to unveil this hypothesis given its implication in disease epidemiology and management.

Based on multiple-locus variable-number analysis, strains isolated from diseased cherry laurel in the Netherlands were clustered in two groups (10). Likewise, based on fluorescent amplified fragment length polymorphism and housekeeping genes, Boudon et al. (13) analyzed strains isolated from infected stone fruits in western Europe and the United States and reported a low diversity among the strains. The authors also found the same bacterial genotype in five countries on three continents. A recent study, based on the housekeeping genes from a worldwide collection of strains, further validated a lack of relationship among strains due to geographic origin (33). This almost clonal global population can be associated with the limited genetic diversity of its host $(13,112)$. In contrast, a high genetic diversity was reported among strains of $X$. arboricola isolated from walnut, where relationship among strains due to geographic origin was possible $(51,85)$. This could be because Persian walnut is propagated by locally grown seeds adapted to different environments, allowing the selection of different $X$. arboricola populations (85). A distinct genetic lineage of $X$. arboricola strains pathogenic to walnut was recently reported, highlighting an even wider diversity among these strains than what was known (32).

\section{Molecular Basis of Xanthomonas arboricola Pathogenesis on Woody Plants}

The advent of the genomic era has provided insights into several controversial issues concerning plant-microbe interaction. There has been little progress to date with $X$. arboricola, which can be mainly attributed to the lack of whole genome sequences. However, given the economic importance of $X$. arboricola diseases on woody plants, there are several ongoing studies on the molecular basis of this pathogen's interactions with its hosts. Although different studies underlined the role of host selection in the population structure of individual $X$. arboricola strains $(32,73)$, other important aspects need to be addressed. Of special importance are environmental selection, gene flow, and genetic drift, which can influence the overall population structure of the pathogen. A recent study based on the type III effector genes of all seven pathovars of $X$. arboricola revealed that type III effector repertoires vary in size among the intraspecific pathovars (73). In particular, the Prunus spp., hazelnut, and Juglans spp. strains were reported to have the largest type III effector repertoires compared to other $X$. arboricola pathovars. The type III secretion system is known to be fundamental to parasitic fitness and pathogenicity (4). Our lack of host range knowledge within $X$. arboricola, however, inhibits understanding of whether a larger number of effector repertoires among its pathovars of stone fruits and nuts could be correlated with their capacity to attack a broader host range. Two other scenarios can be proposed. First, the higher number of effector repertoires could be due to a redundancy of the type III secretion proteins (i.e., homologous effectors), similar to other pathosystems $(27,45)$. And second, since all of these pathovars carrying a larger number of effector repertoires attack woody plants, it can be speculated that among these effectors are some that are involved in degrading woody tissues or compounds that constitute the secondary lignin typical of woody plants (5). If these pathovars can degrade lignin, this information might be essential in breeding for resistance to $X$. arboricola.

The understanding of the molecular basis among individual pathogens and their specific hosts needs to be accelerated through advances in genomic sequencing. Whole genome sequences of a strain from hazelnut (35) and another from peach (75) were recently completed. The release of these genomes represents a significant contribution toward research on the pathogenesis of $X$. arboricola on woody plants. Future studies based on comparative genomic analyses are needed to identify underlying molecular mechanisms that promote the evolution and adaptation of the pathogen to diverse environments and host plants. A recent study identified a new genetic lineage within $X$. arboricola that causes a 
more severe disease on walnut than those previously reported (32). The underlying forces that led to the emergence of a new $X$. arboricola disease should be the subject of future investigations. It is especially important to understand the acquisition of virulenceassociated genes by horizontal gene transfer, the occurrence of accessory and mobile genetic elements, and spontaneous mutations among $X$. arboricola pathovars (33).

\section{Breeding for Resistance}

Host resistance is an important component of integrated pest management. However, little work has been done describing resistance against $X$. arboricola. The paradox of fruit and nut trees resistance to $X$. arboricola diseases is that either sources of resistance are not known or resistant cultivars lack specific desirable fruit and marketing characteristics. Breeding programs should therefore focus on the introgression of resistance to commercial cultivars from other sources, such as wild species or others with less acceptable marketing characteristics. Also, the possibility of exploiting genetic engineering for the development of resistant cultivars needs to be considered. An example is resistance breeding in the United States, where a breeding program has released cultivars of peach resistant to $X$. arboricola $(65,66$; Table 2). Despite the availability of highly resistant peach cultivars $(43,89,105)$, however, considerable variation among these cultivars has been reported in disease incidence from year to year since weather conditions are of the greatest importance for the onset and development of epidemics. According to Yang et al. (108), in years with climatic conditions favorable for infection, all of these genotypes showed at least some symptoms. This suggests the need of a more durable multi-gene resistance to the pathogen.

Marker-assisted breeding has been used recently to develop stone fruit varieties with resistance or increased tolerance to $X$. arboricola. Socquet-Jugard and others (92) identified a microsatellite marker (UDAp-452) on apricot co-segregated with resistance to $X$. arboricola and two flanking microsatellites (BPPCT037 and BPPCT038A). The authors demonstrated that when dividing the population according to the alleles of UDAp-452, the subgroup with the unfavorable allele had a higher disease incidence than the group with the favorable allele. Use of the favorable allele led to a reduction in disease incidence of $35.6 \%$. Likewise, different peach genotypes obtained from a cross between susceptible and resistant plants have been used to construct linkage maps and to map quantitative trait loci (QTLs) (108). More specifically, 14 QTLs with an additive effect on $X$. arboricola resistance were detected, including four major QTLs on linkage groups (LG) 1, 4, 5, and 6. It was observed that two major QTLs, Xap.Pp.OC-4.1 and Xap.Pp.OC4.2 , on LG4 were associated with $X$. arboricola resistance in leaves. Similarly, the QTL Xap.Pp.OC-5.1 on LG5 was associated with bacterial resistance in both leaves and fruits, while Xap.Pp.OC-1.2 on LG1 and Xap.Pp.OC-6.1 on LG6 were only associated with pathogen resistance in fruit. Collectively, these results suggest a separate regulation of leaf and fruit resistance to $X$. arboricola in peach as well as participation of genes involved in general plant response to biotic stress $(92,108)$.

Table 2. Peach, plum and walnut accessions/cultivars resistant to Xanthomonas arboricola

\begin{tabular}{lclc}
\hline Species & Country & \multicolumn{1}{c}{ Accessions or cultivars } & References \\
\hline Peach & USA & Clayton, Cador, Senitel & 66,80 \\
Plum & USA & $\begin{array}{l}\text { Robusto, Segundo, } \\
\text { Rubysweet, Bruce }\end{array}$ & 98 \\
Walnut & China & Jinboxiang 3 & 96 \\
& & Yunxin Gaoyuan & 107 \\
& & Yunxin 90303 & 117 \\
& & Luguo 4 & 116 \\
& Slovenia & Krnc, Z-60, Z-62 & 93 \\
& Turkey & 19 Genotypes & 3 \\
\hline
\end{tabular}

Although the above studies represent a first step toward markerassisted breeding of new stone fruit varieties with an increased tolerance to $X$. arboricola, to date no tightly linked markers or isolation of genes associated with pathogen resistance have been reported. Both peach and apricot are likely to suffer from low-density linkage maps and not enough diversity between parents to allow for more markers to be analyzed (108).

Understanding gene functions and molecular mechanisms underlying disease resistance is important for breeding programs. For example, release of the peach genome v1.0. in 2010 (http:// www.rosaceae.org/gb/gbrowse/prunus_persica/) led to a candidate gene search between the two flanking markers BPPCT037 and BPPCT038A. Between the two flanking markers, three putative genes encoding leucine-rich repeat (LRR) receptor-like serine/ threonine kinases were found using the peach genome annotations. Moreover, two genes encoding putative disease-resistance proteins and one encoding a putative F-box/LRR-repeat protein were found in this region. The availability of the peach genome sequence $v 1$ and the growing availability of single nucleotide polymorphism markers $(2,103)$ may encourage studies to develop high-density linkage maps and discover QTLs associated with important agronomic traits.

Susceptibility tests of different Juglans genotypes to $X$. arboricola in field trials showed no symptoms on J. nigra and widespread symptoms on J. regia (9). J. regia is the most important commercial variety of walnut and is often severely damaged by $X$. arboricola $(9,26)$. Frutos $(26)$ summarized an in-depth report on new accessions of $J$. regia and their behavior to the pathogen. However, this report only summarized some important accessions of $J$. regia from around the world with satisfactory levels of resistance to $X$. arboricola (Table 2). Aside from the resistance observed on $J$. nigra, field inoculation tests demonstrated an increasing order of susceptibility of $J$. cinerea, J. sieboldiana, $J$. mandshurica, and J. bindsii to the pathogen X. arboricola (9).

\section{Disease Management}

The management of a given disease should be based on the combination of several control measures. This requires an in-depth knowledge of the biology of a host and its pathogen as well as epidemiology of the disease. The use of healthy planting material excludes introduction of the pathogen in its latent form. To this aim, effective early detection methods are essential (see below). Once the pathogen is established in an area, control measures should be applied to reduce pathogen inoculum. Effective cultural practices such as treatment with copper-based compounds, elimination of the infected plant parts, and optimization of fertilization and irrigation practices are among the most important interventions to reduce the pathogen inoculum. In addition, elimination of weeds and orchard grasses is needed when they constitute a potential pathogen reservoir. Genetic diversity of the crop can be improved by planting mixed varieties or cultivars instead of a single variety or cultivar. Intercropping is another practice that might significantly reduce pathogen inoculum pressure and the consequent yield losses.

Concerning the use of healthy planting materials to control $X$. arboricola diseases, in Europe, phytosanitary measures, based on nursery inspections and implementation of the EPPO-approved certification scheme, should still be greatly improved to ensure the production of healthy planting materials. In the United States, nursery inspections and certification are a part of integrated pest management under the responsibility of the U.S. Department of Agriculture, Animal and Plant Health Inspection Service (USDAAPHIS), because $X$. arboricola, as many plant-pathogenic bacteria, is commonly present as an epiphyte or endophytically as a latent infection where symptoms are not always expressed $(31,49)$. Indeed, early detection of the pathogen in nursery materials is the only way to avoid its movement through global trade. International trade of plants and plant products is a major cause of rapid longdistance dissemination of bacterial pathogens. This underscores the need of molecular-based rapid diagnostic tests to determine the 
presence of this pathogen in plant tissues, especially nursery materials. Development of these detection methods, however, should take into account pathogen diversity and not focus on a specific strain or pathovar. This is necessary to ensure the diagnostic confidence of a given method for pathogen detection. These methods must also be sensitive enough to detect very low numbers of bacteria. There are several recently developed early detection methods for $X$. arboricola (see 47 for detail), but further efforts are needed to improve the sensitivity of these methods.

The scarcity of resistant germplasm and the strong influence of weather conditions on disease development often represent a serious constraint in the management of $X$. arboricola diseases. Further, only a few effective yet economical bactericides are available, making control of bacterial diseases extremely difficult (1). Often, copper-based compounds are used in European countries to control $X$. arboricola. This has led to the development of several copperresistant strains of the pathogen, such as those isolated from walnut orchards where intensive copper-based treatments were applied (29).

Once $X$. arboricola is present in a production area, its inoculum level must be reduced to limit crop damage. Periodic monitoring and quantification of epiphytic populations using effective techniques (48) is needed to avoid the under- or overestimation of the epiphytic population density. Once the population density exceeds the economic threshold, preventive treatments based on copperbased compounds should be applied to reduce inoculum levels. When symptoms of infection appear, pruning and elimination of infected plant parts, sealing of wounds, and applications of copperbased bactericides are recommended for control (47). The application of these compounds should follow events causing wounds on plants including autumn leaf fall, which provides several ports of entry for the pathogen (109). In addition, lesions caused by spring frost and hail are ideal infection ports for bacterial pathogens (49), and for this reason such events must be followed by prompt copper-based treatments.

Although copper-based formulations satisfactorily control epiphytic bacterial populations (88), they are ineffective once the pathogen enters the plant. These are contact pesticides and cannot reach pathogen populations inside dormant buds or cankers. Another constraint to the use of these products on Prunus spp. is damage to leaves and fruit (44). Undesired effects of copper on walnut tree performance and its fruit phytosanitary status have also been recorded (78). Because of these negative effects, alternatives to copper compounds are being sought. Alternatives have included the application of chemicals such as acibenzolar-S-methyl, an inducer of systemic acquired resistance (SAR) and prohexadione calcium, a growth regulator to control bacterial diseases (see 49 for detail). Moreover, several antimicrobial peptides, terpenes, and chitosans have been proposed as alternatives to conventional antibiotics (17) and might find promising applications in $X$. arboricola disease control. The effectiveness of these products in containing $X$. arboricola infection, however, still need to be tested under field conditions.

Little is known about the effectiveness of biological control agents to manage $X$. arboricola diseases of woody plants. However, there are some reports on the use of antagonistic bacteria to control X. arboricola disease on Prunus spp. $(11,42)$ and walnut (67). Finally, although bacteriophages have been used successfully to manage several Xanthomonas diseases of annual plants (41), little progress has been made to control $X$. arboricola on woody plants. The only example in the literature on the use of selected bacteriophages to control $X$. arboricola disease is on peach (114). The authors reported that bacteriophages obtained from affected peach orchards are effective against $X$. arboricola disease on peach. This encourages the future study in finding alternatives to chemical compounds.

\section{Closing Remarks and Perspectives}

Crop loss assessments have been made for major annual crops (64), but little information is available for perennial crops (34).
Especially, estimation of crop losses due to $X$. arboricola will help to accurately define the importance of the diseases caused by this pathogen globally.

A better understanding of $X$. arboricola epidemiology is needed to improve cultural practices. Especially, the survival of the pathogen in the soil and irrigation water needs more attention given the existing knowledge gap. Research should be intensified to find alternatives to traditional chemical compounds for disease management; biological control and plant resistance especially need more focus.

Genetic studies of $X$. arboricola interactions with woody host plants need to be intensified. The availability of whole genome sequences should be exploited for comparative genomic analyses and also to pinpoint molecular mechanisms involved in the evolution and adaptation of the pathogen to diverse environments and host plants. Critical knowledge of the effector complement necessary for woody tissue invasion, canker formation, and systemic movement needs to be gained through comparative genomic analyses and subsequent genetic studies. These may lead to improved host resistance and could be the best means for control of $X$. arboricola diseases difficult to manage with conventional chemicals.

\section{Acknowledgments}

My sincere thanks to Prof. Robert C. Seem, Cornell University, USA, whose incredible patience and insightful feedback increased the quality of this manuscript. A special thanks to the two anonymous reviewers for the critical revision and many constructive suggestions on the manuscript. I also thank Dr. Maria M.

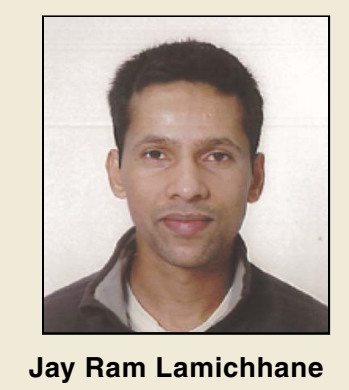

Dr. Lamichhane is a postdoctoral research associate at French National Institute for Agricultural Research (INRA), Grignon, France. He obtained a B.Sc. and his M.Sc. honors in agricultural sciences in 2005 and 2007, respectively, at the University of Tuscia, Viterbo, Italy. He then received a Ph.D. degree in 2011 in plant protection at the same university where he also worked as a PostDoc fellow for more than two years. Dr. Lamichhane's research focuses on the epidemiology and control of diseases caused by plant-pathogenic Pseudomonas syringae and Xanthomonas arboricola both on annual and on woody crops. However, he also has experience with beneficial (endophytic, epiphytic, and plant-growth-promoting rhizobacteria) and other phytopathogenic bacteria (Agrobacterium tumefaciens, Clavibacter michiganensis, Pectobacterium carotovorum, and Xanthomonas spp.), fungi (Cytospora, Fusarium), and oomycetes (Phytophthora). At the beginning of 2013, Dr. Lamichhane moved to France as a visiting PostDoc fellow. At the time, he worked on the host range determination of plant-pathogenic Pseudomonas syringae species complex at INRA, Plant Pathology Research Unit in Avignon. Since April 2014, he has been actively involved both in research and in coordination of European Research Area Network (ERANet). More specifically, he is involved within the EU funded ERA-Net project on coordinated integrated pest management and European Network for the Durable Exploitation of Crop Protection Strategies (ENDURE). Within these European networks, he focuses mainly on topics related to crop protection through an effective implementation of integrated pest management strategies. 
Lopez of Centro de Proteccion Vegetal y Biotecnologia, IVIA, Spain, for suggesting authors with photos of disease symptoms. I am grateful to Dr. Antonia Ninot of Departament d'Arboricultura Mediterrània, IRTA, Centre de Mas Bové, Spain; Dr. Daiva Burokiene of the Institute of Botany at the Nature Research Centre, Vilnius, (Lithuania); Dr. Katherine Evans of Tasmanian Institute of Agriculture, Tasmania, Australia for providing the photos of $X$. arboricola symptoms on walnut. A special thanks to Dr. Miguel Cambra of Centro de Protección Vegetal, CPV, Aragón, Spain for providing a large number of excellent pictures showing symptoms on Prunus species.

\section{Literature Cited}

1. Agrios, G. 2005. Plant Pathology, 5th ed. Academic Press, New York.

2. Ahmad, R., Parfitt, D. E., Fass, J., Ogundiwin, E., Dhingra, A., Gradziel, T. M., Lin, D., Joshi, N. A., Martinez-Garcia, P. J., and Crisosto, C. H. 2011. Whole genome sequencing of peach (Prunus persica L.) for SNP identification and selection. BMC Genomics 12:569.

3. Akca, Y., and Ozongun, S. 2004. Selection of late leafing, late flowering, laterally fruitful walnut (Juglans regia) types in Turkey. N.Z. J. Crop Hortic. Sci. 32:337-342.

4. Alfano, J. R., Charkowski, A. O., Deng, W. L., Badel, J. L., PetnickiOcwieja, T., van Dijk, K., and Collmer, A. 2000. The Pseudomonas syringae Hrp pathogenicity island has a tripartite mosaic structure composed of a cluster of type III secretion genes bounded by exchangeable effector and conserved effector loci that contribute to parasitic fitness and pathogenicity in plants. Proc. Natl. Acad. Sci. USA 97:4856-4861.

5. Bartoli, C., Lamichhane, J. R., Berge, O., Guilbaud, C., Varvaro, L., Balestra, G. M., Vinatzer, B. A., and Morris, C. E. 2014. A framework to gauge the epidemic potential of plant pathogens in environmental reservoirs: The example of kiwifruit canker. Mol. Plant Pathol. doi: 10.1111/ mpp. 12167

6. Battilani, P., Rossi, V., and Saccardi, A. 1999. Development of Xanthomonas arboricola pv. pruni epidemics on peaches. J. Plant Pathol. 81:161171.

7. Bazzi, C., and Mazzucchi, U. 1980. Epidemia di Xanthomonas pruni su susino. Inform. Fitopatol. 30:11-17.

8. Belisario, A., Maccaroni, M., Corazza, L., Balmas, V., and Valier, A. 2002. Occurrence and etiology of brown apical necrosis on Persian (English) walnut fruit. Plant Dis. 86:599-602.

9. Belisario, A., Zoina, A., Pezza, L., and Luongo, L. 1999. Susceptibility of species of Juglans to pathovars of Xanthomonas campestris. Eur. J. Plant Pathol. 29:75-80.

10. Bergsma-Vlami, M., Martin, W., Koenraadt, H., Teunissen, H., Pothier, J. F., Duffy, B., and van Doorn, J. 2012. Molecular typing of Dutch isolates of Xanthomonas arboricola pv. pruni isolated from ornamental cherry laurel. J. Plant Pathol. 94:S129-S135.

11. Biondi, E., Dallai, D., Brunelli, A., Bazzi, C., and Stefani, E. 2009. Use of a bacterial antagonist for the biological control of bacterial leaf/fruit spot of stone fruits. IOBC Bull. 43:277-281.

12. Blomhoff, R., Carlsen, M. H., Andersen L. F., and Jacobs, D. R., Jr. 2006. Health benefits of nuts: Potential role of antioxidants. Br. J. Nutr. 96:S5260 .

13. Boudon, S., Manceau, C., and Nottéghem, J.-L. 2005. Structure and origin of Xanthomonas arboricola pv. pruni populations causing bacterial spot of stone fruit trees in western Europe. Phytopathology 95:1081-1088.

14. Burkholder, W. H. 1957. .Xanthomonas. Pages 152-183 in: Bergey's Manual of Determinative Bacteriology, 7th ed. R. S. Breed, E. G. D. Murray, and N. R. Smith, eds. Williams \& Wilkins Press, Baltimore, MD.

15. Burokiene, D., and Pulawska, J. 2012. Characterization of Xanthomonas arboricola pv. juglandis isolated from walnuts in Lithuania. J. Plant Pathol. 94:S123-S127.

16. CABI-EPPO. 2001. Xanthomonas arboricola pv. juglandis. Distribution maps of plant diseases. CABI-EPPO. p. 133.

17. Cameron, A., and Sarojini, V. 2014. Pseudomonas syringae pv. actinidiae: Chemical control, resistance mechanisms and possible alternatives. Plant Pathol. 63:1-11.

18. Civerolo, E. L. 1975. Quantitative aspects of pathogenesis of Xanthomonas pruni in peach leaves. Phytopathology 65:258-264.

19. Davis, J. R., and English, H. 1969. Factors related to the development of bacterial canker in peach. Phytopathology 59:588-595.

20. Dye, D. W., Bradbury, J. F., Goto, M., Hayward, A. C., Lelliott, R. A., and Schroth, M. N. 1980. International standards for naming pathovars of phytopathogenic bacteria and a list of pathovar names and pathotype strains. Rev. Plant Pathol. 142:153-158.

21. EPPO/OEPP. 2004. Diagnosis protocols for regulated pests Xanthomonas arboricola pv. corylina. EPPO Bull. 179:179-181.

22. EPPO/OEPP. 2006. Diagnostics Xanthomonas arboricola pv. pruni. EPPO Bull. 36:129-133.

23. EPPO/OEPP. 2006. Data Sheets on Quarantine Pests. Xanthomonas arboricola pv. pruni. http://www.eppo.org/QUARANTINE/listA2.htm

24. Fahy, P. C., and Persley, G. J. 1983. Plant Bacterial Diseases: A Diagnostic Guide. Academic Press, New South Wales, Australia.

25. FAO. 2012. FAO statistics. http://www.faostat.fao.org/site/339/default. aspx.644 Accessed 17 February 2014.

26. Frutos, D. 2010. Bacterial diseases of walnut and hazelnut and genetic resources. J. Plant Pathol. 92:79-85.

27. Galán, J. E. 2009. Common themes in the design and function of bacterial effectors. Cell Host Microbe. 5:571-579.

28. Garcin, A., and Duchesne, D. 2001. Walnut blight and apical necrosis Acta. Hortic. 705:447-449.

29. Gardan, L., Brault, T., and Germain, E. 1993. Copper resistance of Xanthomonas campestris pv. juglandis in French walnut orchards and its association with conjugative plasmids. Acta. Hortic. 311:259-265.

30. Golmohammadi, M., Alizadeh, A., and Rahimian, H. 2002. Homogeneity of the strains inciting bacterial blight of walnut in the central and northern provinces of Iran. Iranian J. Plant Pathol. 38:11-20.

31. Goodman, C. A., and Hattingh, M. J. 1986. Transmission of Xanthomonas campestris pv. pruni in plum and apricot nursery trees by budding. Hortscience 21:995-996.

32. Hajri, A., Meyer, D., Delort, F., Guillaumes, J., Brin, C., and Manceau, C. 2010. Identification of a genetic lineage within Xanthomonas arboricola pv. juglandis as the causal agent of vertical oozing canker of Persian (English) walnut in France. Plant Pathol. 59:1014-1022.

33. Hajri, A., Pothier, J. F., Fischer-Le, Saux, M., Bonneau, S., Poussier, S., Duddy, B., and Manceau, C. 2012. Type three effector gene distribution and sequence analysis provide new insights into the pathogenicity of plantpathogenic Xanthomonas arboricola. Appl. Environ. Microbiol. 78:371384.

34. Heaton, C. R., Ogawa, J. M., and Nyland, G. 1981. Evaluating economic losses caused by pathogens of fruit and nut crops. Plant Dis. 65:886-888.

35. Ibarra-Caballero, J., Zerillo, M. M., Snelling, J., Boucher, C., and Tisserat, N. 2013. Genome sequence of Xanthomonas arboricola pv. corylina, isolated from Turkish filbert in Colorado. Gen. Announce. 1:e00246-13.

36. Jami, F., Kazempour, M. N., Elahinia, S. A., and Khodakaramian, G. 2005. First report of Xanthomonas arboricola pv. pruni on stone fruit trees from Iran. J. Phytopathol. 153:371-372.

37. Janick, J. 2005. The origins of fruits, fruit growing, and fruit breeding. Plant Breed. 25:255-320.

38. Janse, J. D. 2010. Diagnostic methods for phytopathogenic bacteria of stone fruits and nuts in COST 873. EPPO Bull. 40:68-85.

39. Janse, J. D., Rossi, M. P., Gorkink, R. F. J., Derks, J. H. J., Swings, J., Janssens, D., and Scortichini, M. 2001. Bacterial leaf blight of strawberry (Fragaria (x) ananassa) caused by a pathovar of Xanthomonas arboricola, not similar to Xanthomonas fragariae Kennedy \& King. Description of the causal organism as Xanthomonas arboricola pv. fragariae (pv. nov., comb. nov.). Plant Pathol. 50:653-665.

40. Janse, J. D., and Wenneker, M. 2002. Possibilities of avoidance and control of bacterial plant diseases when using pathogen-tested (certified) or treated planting material. Plant Pathol. 51:523-536.

41. Jones, J. B., Jackson, L. E., Balogh, B., Obradovic, A., Iriarte, F. B., and Momol, M. T. 2007. Bacteriophages for plant disease control. Annu. Rev. Phytopathol. 45:245-262.

42. Kawaguchi, A., Inoue, K., and Inoue, Y. 2014. Biological control of bacterial spot on peach by non pathogenic Xanthomonas campestris strains AZ98101 and AZ98106. J. Gen. Plant Pathol. doi: 10.1007/s10327-0140506-6

43. Keil, H. L., and Fogle, H. W. 1974. Orchard susceptibility of some apricot, peach, and plum cultivars and selections to Xanthomonas pruni. Fruit Var. J. 28:16-19.

44. Kennelly, M. M., Cazorla, F. M., De Vicente, A., Ramos, C., and Sundin, G. W. 2007. Pseudomonas syringae diseases of fruit trees: Progress toward understanding and control. Plant Dis. 91:4-17.

45. Kvitko, B. H., Park, D. H., Velásquez, A. C., Wei, C. F., Russel, A. B., Martin, G. B., Schneider, D. J., and Collmer, A. 2009. Deletions in the repertoire of Pseudomonas syringae pv. tomato DC3000 type III secretion effector genes reveal functional overlap among effectors. PLoS Pathog.5: e1000388.

46. Lamichhane, J. R., Fabi, A., Ridolfi, R., and Varvaro, L. 2013. Epidemiological study of hazelnut bacterial blight in central Italy by using laboratory analysis and geostatistics. PLoS ONE8: e56298.

47. Lamichhane, J. R., and Varvaro, L. 2014. Xanthomonas arboricola disease of hazelnut: Current status and future perspectives for its management. Plant Pathol. 63:243-254.

48. Lamichhane, J. R., and Varvaro, L. 2014. Comparison of methods used in the recovery of phylloplane bacteria: A case study of Pseudomonas savastanoi pv. savastanoi applied to the phylloplane of Olea europaea sub-species. J. Plant Prot. Res. 54:22-27.

49. Lamichhane, J. R., Varvaro, L., Parisi, L., Audergon, J.-M., and Morris, C E. 2014. Disease and frost damage of woody plants caused by Pseudomonas syringae: Seeing the forest for the trees. Adv. Agron. 126:235-295.

50. Lang, M. D., and Evans, K. J. 2010. Epidemiology and status of walnut blight in Australia. J. Plant Pathol. 92:S149-S155.

51. Loreti, S., Gallelli, A., Belisario, A., Wajnberg, E., and Corazza, L. 2001. Investigation of genomic variability of Xanthomonas arboricola pv. juglandis by AFLP analysis. J. Plant Pathol. 107:583-591.

52. Malvick, D. K., and Moore, L. W. 1988. Population dynamics and 
diversity of Pseudomonas syringae on maple and pear trees and associated grasses. Phytopathology 78:1366-1370.

53. Manning, W. E. 1978. The classification within the Juglandaceae. Ann. Missouri Bot. Gard. 65:1058-1087.

54. Marchi, G., Cinelli, T., and Surico, G. 2011. Bacterial leaf spot caused by the quarantine pathogen Xanthomonas arboricola pv. pruni on cherry laurel in central Italy. Plant Dis. 95:74.

55. Matthee, F. N., and Daines, R. H. 1968. Effect of soil types and substrate aeration on stomatal activity, water diffusion pressure deficit, water congestion, and bacterial infection of peach and pepper foliage. Phytopathology 58:1298-1301.

56. Matthee, F. N., and Daines, R. H. 1969. The influence of nutrition on susceptibility of peach foliage to water congestion and infection by Xanthomonas pruni. Phytopathology 59:285-287.

57. Miles, W. G., Daines, R. H., and Rue, J. W. 1977. Pre-symptomatic egress of Xanthomonas pruni from infected peach leaves. Phytopathology 67:895-897.

58. Moffett, M. L. 1973. Bacterial spot of stone fruit in Queensland. Aust. J. Biol. Sci. 26:171-179.

59. Moragrega, C., Matias, J., Aletà, N., Montesinos, E., and Rovira, M. 2011. Apical necrosis and premature drop of persian (English) walnut fruit caused by Xanthomonas arboricola pv. juglandis. Plant Dis. 95:1565-1570.

60. Mulrean, E. N., and Schroth, M. N. 1982. Ecology of Xanthomonas campestris pv. juglandis on Persian (English) walnut. Phytopathology 72:434-438.

61. Myung, I., Moon, S. Y., Jeong, I. H., Lee, S. W., and Ra, D.-S. 2010. A new disease, bacterial fruit rot of jujube, caused by Xanthomonas arboricola in Korea. New Dis. Rep. 22:12.

62. Myung, I. S., Jeong, I. H., Moon, S. Y., Moon, S. Y., Lee, S. W., and Shim, H. S. 2010. A new disease, arboricola leaf spot of bell pepper, caused by Xanthomonas arboricola. Plant Dis. 94:271.

63. Ninot, A., Aletà, N., Moragrega, C., and Montesinos, E. 2002. Evaluation of a reduced copper spraying program to control bacterial blight of walnut. Plant Dis. 86:583-587.

64. Oerke, E. C. 2006. Crop losses to pests. J. Agric. Sci. 144:31-43.

65. Okie, W. R. 1998. Handbook of peach and nectarine varieties-performance in the southeastern United States and index of names. USDA/ARS Agriculture.

66. Okie, W. R., Bacon, T., and Bassi, D. 2008. Fresh Market Cultivar Development. Pages 139-174 in: The peach: Botany, production and uses. D. R. Layne and D. Bassi, eds. CAB International, Cambridge.

67. Ozaktan, H., Erdal, M., Akkopru, A., and Aslan, E. 2012. Biological control of bacterial blight of walnut by antagonistic bacteria. J. Plant Pathol. 94S:53-56.

68. Özaktan, H., Erdal, M., Akkopru, A., and Aslan, E. 2007. Evaluation of susceptibility of some walnut cultivars to Xanthomonas arboricola pv. juglandis by immature nut test. Cost 873 , WG3/WG4 joint meeting, Murcia. http://www.cost873.ch/_uploads/ files/m_ozaktan_murcia.PDF

69. Pagani, M. C. 2004. An ABC transporter protein and molecular diagnoses of Xanthomonas arboricola pv. pruni causing bacterial spot of stone fruits. Ph.D. thesis. University of North Carolina, Raleigh.

70. Palacio-Bielsa, A., Cubero, J., Cambra, M. A., Collados, R., Berruete, I. M., and Lopez, M. M. 2011. Development of an efficient real-time quantitative PCR protocol for detection of Xanthomonas arboricola pv. pruni in Prunus species. Appl. Environ. Microbiol. 77:89-97.

71. Palacio-Bielsa, A., Roselló, M., Cambra, M. A., and Lopez, M. M. 2010. First report on almond in Europe of bacterial spot disease of stone fruits caused by Xanthomonas arboricola pv. pruni. Plant Dis. 94:786.

72. Palleroni, N. J., Hildebrand, D. C., Schroth, M. N., and Hendson, M. 1993. Deoxyribonucleic acid relatedness of 21 strains of Xanthomonas species and pathovars. J. Appl. Bacteriol. 75:441-446.

73. Pothier, J. F., Pagani, M. C., Pelludat, C., Ritchie, D. F., and Duffy, B. 2011. A duplex-PCR method for species- and pathovar-level identification and detection of the quarantine plant pathogen Xanthomonas arboricola pv. pruni. J. Microbiol. Methods 86:16-24.

74. Pothier, J. F., Pelludat, C., Bounter, M., Genini, M., Vogelsanger, J., and Duffy, B. 2010. First report of the quarantine pathogen Xanthomonas arboricola pv. pruni on apricot and plum in Switzerland. Plant Pathol. 59:404.

75. Pothier, J. F., Smits, T. H., Blom, J., Vorhoelter, F., Goesmann, A., Puehler, A., and Duffy, B. 2011. Complete genome sequence of the stone fruit pathogen Xanthomonas arboricola pv. pruni. (Abstr.) Phytopathology 101:S144.

76. Qi, Y. X., Pu, J. J., Zhang, X., Lu, Y., Zhang, H., Lu, Y. C., Zhang, H. Q., and Xie, Y. X. 2012. First report of bacterial leaf spot of mango caused by a Xanthomonas arboricola pathovar in China. J. Plant Pathol. 94:S4.85.

77. Rademaker, J. L. W., Louws, F. J., Schultz, M. H., Rossbach, U., Vauterin, L., Swings, J., and de Bruijn, F. J. 2005. A comprehensive species to strain taxonomic framework for Xanthomonas. Phytopathology 95:1098-1111.

78. Radix, P., Bastien, C., Jay-Allemand, C., Charlot, G., and Seigle-Murandi, F. 1998. The influence of soil nature on polyphenols in walnut tissues. A possible explanation of differences in the expression of walnut blight. Agronomie 18:627-637

79. Ritchie, D. F. 1995. Bacterial spot. Pages 50-52 in: Compendium of Stone
Fruit Diseases. J. M. Ogawa, E. I. Zehr, G. W. Bird, D. F. Ritchie, K. Uriu, and J. K. Uyemoto, eds. American Phytopathological Society, St. Paul, MN.

80. Ritchie, D. F. 1999. Sprays for control of bacterial spot of peach cultivars having different levels of disease susceptibility. Fungic. Nematicide Tests 53:63-64.

81. Roselló, M., Santiago, R., Palacio-Bielsa, A., Garcia-Figueres, F., Monton, C., Cambra, M. M., and Lopez, M. M. 2012. Current status of bacterial spot of stone fruits and almond caused by Xanthomonas arboricola pv. pruni in Spain. J. Plant Pathol. 94:S115-S121.

82. Saccardi, A., and Goio, P. 1990. Epidemia di Xanthomonas campestris pv. pruni in pescheti del veronese. Inform. Agrar. 8:117-120.

83. Sawada, H., Kunugi, Y., Watauchi, K., Kudo, A., and Sato, T. 2011. Bacterial spot, a new disease of grapevine (Vitis vinifera) caused by Xanthomonas arboricola. Jpn. J. Phytopathol. 77:7-22. (in Japanese)

84. Scortichini, M. 2010. Epidemiology and predisposing factors of some major bacterial diseases of stone and nut fruit trees species. J. Plant Pathol. 92:S173-S178.

85. Scortichini, M., Marchesi, U., and Di Prospero, P. 2001. Genetic diversity of Xanthomonas arboricola pv. juglandis (synonyms: X. campestris pv. juglandis; $X$. juglandis pv. juglandis) strains from different geographical areas shown by repetitive polymerase chain reaction genomic fingerprinting. J. Phytopathol. 149:325-332.

86. Shapland, E. B., Daane, K. M., Yokota, G. Y., Wistrom, C., Connell, J. H., Duncan, R. A., and Viveros, M. A. 2006. Ground vegetation survey for Xylella fastidiosa in California almond orchards. Plant Dis. 90:905-909.

87. Shen, Y. M., Huang, T. C., Chao, C. H., and Liu, H. L. 2013. First report of bacterial spot caused by Xanthomonas arboricola pv. pruni on Japanese plum in Taiwan. Plant Dis. 97:835.

88. Shepard, D. P., and Zehr, E. I. 1994. Epiphytic presence of Xanthomonas campestris pv. pruni on peach and plum. Plant Dis. 78:627-629.

89. Simeone, A. M. 1985. Study on peach and nectarine cultivars susceptibility to the main fungus and bacteria. Acta Hortic. 173:541-551.

90. Smith, E. F. 1903. Observation on a hitherto unreported bacterial disease, the cause of which enters the plant through ordinary stomata. Science 17:456-457

91. Smith, R. E., Smith, C. O., and Ramsey, H. J. 1912. Walnut culture in California and walnut blight. Calif. Agric. Exp. Stn. Bull. 231:119-398.

92. Socquet-Juglard, D., Duffy, B., Pothier, J. F., Christen, D., Gessler, C., and Patocchi, A. 2013. Identification of a major QTL for Xanthomonas arboricola pv. pruni resistance in apricot. Tree Genet. Genome 9:409-421.

93. Solar, A. 2006. Evaluation of some perspective walnut genotypes in Slovenia. Acta Hortic. 705:131-136.

94. Stefani, E. 2010. Economic significance and control of bacterial spot/canker of stone fruits caused by Xanthomonas arboricola pv. pruni. J. Plant Pathol. 92(S1):99-103.

95. Stratil, P., Klejdus, B., and Kuban, V. 2007. Determination of phenolic compounds and their antioxidantactivity in fruits and cereals. Talanta 71:1741-1751.

96. Tian, J. B., Wang, Y., Shao, K.-J., Cheng, E. M., Chen, Q.-F., Han, Y.-H., and Han, F. 2008. A new walnut cultivar "Jinboxiang 3." Acta Hortic. Sinica 35:464.

97. Tjou-Tam-Sin, N. N. A., Van de Bilt, J. L. J., Bergsma-Vlami, M., Koenraadt, H., Westerhof, J., van Doorn, J., Pham, K. T. K., and Martin, W. S. 2012. First report of Xanthomonas arboricola pv. pruni in ornamental Prunus laurocerasus in the Netherlands. Plant Dis. 96:759.

98. Topp, B. L., and Sherman, W. B. 1995. Plum bacterial spot resistance in leaves and stems measured by a selection index. Acta Hortic. 403:47-50.

99. Toussaint, V., Benoit, D. L., and Carisse, O. 2012. Potential of weed species to serve as a reservoir for Xanthomonas campestris pv. vitians, the causal agent of bacterial leaf spot of lettuce. Crop Prot. 41:64-70.

100. Van Den Mooter, M., and Swings, J. 1990. Numerical analysis of 295 phenotypic features of 266 Xanthomonas strains and related strains and an improved taxonomy of the genus. Int. J. Syst. Bacteriol. 40:348-369.

101. Vandroemme, J., Cottyn, B., Pothier, J. F., Pfluger, V., Duffy, B., and Maes, M. 2013. Xanthomonas arboricola pv. fragariae: What's in a name? Plant Pathol. 62:1123-1131.

102. Vauterin, L., Hoste, B., Kersters, K., and Swings, J. 1995. Reclassification of Xanthomonas. Int. J. Syst. Evol. Microbiol. 45:472-489.

103. Verde, I., Bassil, N., Scalabrin, S. et al. 2012. Development and evaluation of a 9K SNP array for peach by internationally coordinated SNP detection and validation in breeding germplasm. PLoSOne 7:1-13

104. Watkins, R. 1995. Cherry, plum, peach, apricot and almond: Prunus spp. (Rosaceae). Pages 423-429 in: Evolution of Crop Plants, 2nd ed. J. Smartt and N. W. Simmonds, eds. Longman Scientific and Technical, Essex, England.

105. Werner, D. J., Ritchie, D. F., Cain, D. W. et al. 1986. Susceptibility of peaches and nectarines, plant introductions, and other Prunus species to bacterial spot. HortScience 21:127-130.

106. White, P. J., and Brown, P. H. 2010. Plant nutrition for sustainable development and global health. Ann. Bot. 105:1073-1080.

107. Xi, X. L., Fang, W. L., Fan, Z. Y., et al. 2007. Breeding of new precocious walnut cultivar "Yunxin Gaoyuan." China Fruits 2:7-9.

108. Yang, N., Reighard, G., Ritchie, D., Okie, W., and Gasic, K. 2013. Mapping quantitative trait loci associated with resistance to bacterial spot 
(Xanthomonas arboricola pv. pruni) in peach. Tree Genet. Genome 9:573586.

109. Young, J. M. 1982. A spray programme to control bacterial blast of apricot. Orchard N.Z. 55:413.

110. Young, J. M., Dye, D. W., Bradbury, J. F., Panagopoulos, C. G., and Robbs, C. F. 1978. A proposed nomenclature and classification for plant pathogenic bacteria. N.Z. J. Agric. Res. 21:153-177.

111. Young, J. M., Park, D.-C., Shearman, H. M., and Fargier, E. 2008. A multilocus sequence analysis of the genus Xanthomonas. Syst. Appl. Microbiol. 31:366-377.

112. Zaccardelli, M., Ceroni, P., and Mazzucchi, U. 1999. Amplified fragment length polymorphism fingerprinting of Xanthomonas arboricola pv. pruni. J. Plant Pathol. 81:173-179.

113. Zaccardelli, M., Malaguti, S., and Bazzi, C. 1998. Biological and epidemiological aspects of Xanthomonas arboricola pv. pruni on peach in Italy. J. Plant Pathol. 80:125-132.

114. Zaccardelli, M., Saccaridi, A., Gambin, E., et al. 1994. Xanthomonas campestris pv. pruni bacteriophages on peach trees and their potential use for biological control. VIII Int. Conf. Plant Pathogenic Bacteria. Paris, France. Pages 875-878.

115. Zehr, E. I., and Shepard, D. P. 1996. Bacterial spot of peach as influenced by water congestion, leaf wetness duration and temperature. Plant Dis. 80:339-341.

116. Zhang, M. Y., Xu, Y., and Xiang, K. 2009. Breeding of a new large nut walnut cultivar "Luguo 4." China Fruits 3:1-3.

117. Zhao, T. S., Fang, W. L., Fan, Z. Y., Xi, X.-L., and Zhang, Y. 2007. "Yunxin 90303", a promising new early walnut selection. J. Fruit Sci. 24:252-253. 